Article

\title{
Synthesis, Crystal Structure, Luminescence and Magnetism of Three Novel Coordination Polymers Based on Flexible Multicarboxylate Zwitterionic Ligand
}

\author{
Yulu Ma ${ }^{1,+}$, Lin Du ${ }^{1,+}$, Kaimin Wang ${ }^{2,+}$ and Qihua Zhao ${ }^{1, *}$ \\ 1 Key Laboratory of Medicinal Chemistry for Natural Resource Education Ministry, School of Chemical \\ Science and Technology, Yunnan University, Kunming 650091, China; 22014000171@mail.ynu.edu.cn (Y.M.); \\ lindu@ynu.edu.cn (L.D.) \\ 2 Key Laboratory of Comprehensive Utilization of Mineral Resource in Ethnic Regions, Key Laboratory of \\ Resource Clean Conversion in Ethnic Regions, Education Department of Yunnan, School of Chemistry \& \\ Environment, Yunnan Minzu University, Kunming 650500, China; kmwang041684@163.com \\ * Correspondence: qhzhao@ynu.edu.cn; Tel.: +86-871-5032929 \\ + Those authors contributed equally to this paper.
}

Academic Editor: Helmut Cölfen

Received: 15 December 2016; Accepted: 16 January 2017; Published: 20 January 2017

\begin{abstract}
Three novel zwitterionic coordination polymers, namely, $\left\{\left[\mathrm{Zn}(\mathrm{HCbdcp})_{2}\right] \cdot \mathrm{H}_{2} \mathrm{O}\right\}(\mathbf{1})$, $\left\{[\mathrm{Mn}(\mathrm{Cbdcp})] \cdot 3 \mathrm{H}_{2} \mathrm{O}\right\}(2)$ and $\left\{\left[\mathrm{Cu}_{2}(\mathrm{Cbdcp})(\mathrm{HCbdcp}) \mathrm{Cl} \cdot \mathrm{H}_{2} \mathrm{O}\right] \cdot 2 \mathrm{H}_{2} \mathrm{O}\right\}(3)$, Cbdcp $=3,5$-dicarboxy-1-(4carboxybenzyl)pyridin-1-ium, have been prepared by a hydrothermal method and characterized by X-ray single crystal diffraction analysis, powder X-ray diffraction analysis, IR spectroscopy, and thermogravimetric analysis. With the changing of metal centers, these complexes show distinct structures: a mononuclear 2D $4^{4}$-sql network for 1, a 3D 6,6-connected-type topology for 2 and a novel dinuclear $2 \mathrm{D}$ layer for 3 . These diverse architectures prove that coordination geometry of metal ions, coordination modes of carboxylate groups and the rotationally flexible $\mathrm{CH}_{2}$ linker played significant roles in the construction of CPs; moreover, they also indicated that $\mathrm{H}_{3} \mathrm{CbdcpCl}$ is an ideal organic candidate for the building of novel structures. The solid-state luminescent properties of complexes 1-3 were investigated, respectively. In addition, the magnetic properties of $\mathbf{2}$ and $\mathbf{3}$ were studied and both of them exhibit antiferromagnetic behaviors.
\end{abstract}

Keywords: zwitterionic ligand; crystal structure; coordination polymer; luminescence; magnetic property

\section{Introduction}

Flexible multicarboxylate zwitterionic ligands are one of the intensely studied topics in designing and constructing coordination polymers (CPs) [1-4], for they not only take advantage of carboxylate compounds, but also develop their potentials as flexible ligands. Under hydrothermal conditions or when deprotonated, multicarboxylate groups in flexible multicarboxylate zwitterionic ligands are efficient to create diverse frameworks owing to their mutable linking or coordination modes [5-8]. Moreover, because of the existence of flexible linkers in zwitterionic ligands, such as alkyl and aryl, these kinds of ligands are able to freely bend and rotate in the assembly processes $[9,10]$. Thus, flexible multicarboxylate zwitterionic ligands can be induced to recognize the intrinsic geometric preferences of specific metal ions and to contribute to the structural and topological diversity of CPs. As well as those structural advantages mentioned above, as organic linkers in CPs, flexible multicarboxylate zwitterionic ligands have many other particular properties, which give their CPs potential application as functional materials in magnetism [11-13], optical properties [14-16], 
drug delivery $[17,18]$, gas storage [19] and chemical separation [20,21]. Even though CPs have many values, controlling their frameworks is undoubtedly fundamental for determining the properties and applications of the crystalline materials. However, despite the rapid developments in the construction of a diverse and interesting architectures, many factors in the assembly processes, such as metal ions, counter ions, solvents and temperature still affect the prediction of the precise structure. Thus, obtaining the desirable architectures and the control of structures of CPs with suitable ligands and metal ions remains a long-term challenge to chemists.

In earlier times, Zang and coworkers [22] designed a new zwitterionic ligand, 3,5-dicarboxy-1(4-carboxybenzyl)pyridin-1-ium chloride $\left(\mathrm{H}_{3} \mathrm{CbdcpCl}\right)$, to synthesize three series of lanthanide coordination polymers, which had efficient energy transfer from Cbdcp ligands to $\mathrm{Ln}^{3+}$ ions, generating the characteristic luminescence of corresponding $\mathrm{Ln}^{3+}$ ions. In this paper, the three carboxylate groups of Cbdcp ligand employed chelating bidentate and bidentate bridging in two different coordination modes, which has motivated us to believe that this flexible multicarboxylate zwitterionic ligand $\left(\mathrm{H}_{3} \mathrm{CbdcpCl}\right)$ can make a contribution to the formation of various architectures under the process of self-assembly with transition metals. According to the aforementioned considerations, we chose $\mathrm{H}_{3} \mathrm{CbdcpCl}$ as our organic ligand to react with different d-block metal salts under similar hydrothermal conditions, in order to explore the influence of multicarboxylate groups, the flexible linker and metal ions in the final frameworks. Applying this strategy, here we successfully get three new complexes, namely, $\left\{\left[\mathrm{Zn}(\mathrm{HCbdcp})_{2}\right] \cdot \mathrm{H}_{2} \mathrm{O}\right\}(\mathbf{1}),\left\{[\mathrm{Mn}(\mathrm{Cbdcp})] \cdot 3 \mathrm{H}_{2} \mathrm{O}\right\}(\mathbf{2})$ and $\left\{\left[\mathrm{Cu}_{2}(\mathrm{Cbdcp})(\mathrm{HCbdcp}) \mathrm{Cl} \cdot \mathrm{H}_{2} \mathrm{O}\right] \cdot 2 \mathrm{H}_{2} \mathrm{O}\right\}$ (3). Their syntheses, crystal structures, luminescence and magnetic properties were reported in this paper. Results proved that the Cbdcp ligand is a good candidate to construct novel CPs, for its various coordination modes and its rotationally flexible $\mathrm{CH}_{2}$ linker. In addition, the luminescence properties of $\mathbf{1}$ and the magnetic properties of $\mathbf{2}$ and $\mathbf{3}$ indicate that compound $\mathbf{1}$ may be used as luminescent materials, and $\mathbf{2}$ and $\mathbf{3}$ have potential to be used in magnetic materials.

\section{Results}

\subsection{Crystal Structures}

\subsubsection{Descriptions of the Crystal Structures of $\left\{\left[\mathrm{Zn}(\mathrm{HCbdcp})_{2}\right] \cdot \mathrm{H}_{2} \mathrm{O}\right\}(\mathbf{1})$}

Single-crystal X-ray structure determination revealed that $\mathbf{1}$ crystallizes in the monoclinic crystal system with the Pc space group and exhibits a mononuclear 2D $4^{4}$-sql network structure which is further connected through hydrogen bonds into a 3D supramolecular framework. The asymmetric unit of $\mathbf{1}$ consists of one tetrahedron $\mathrm{Zn}$ (II) ion, two monodentate $\mathrm{HCbdcp}^{-}$ligands and one guest water molecule (Figure 1a). The free benzyl-COO groups are protonated, while the remaining two pyridyl-COO are deprotonated and form carboxylates to balance the positive charge of the pyridinium cation and $\mathrm{Zn}$ (II) center. Each $\mathrm{Zn}$ (II) center coordination from a pair of $\mu_{1}-\eta^{1}$ trans pyridyl-COO groups and a pair of $\mu_{1}-\eta^{1}$ cis pyridyl-COO groups with the $\mathrm{Zn}-\mathrm{O}$ distances fall in a narrow range: 1.953(3)-1.992(3) Å (Table S1). Adjacent Zn(II) centers are bridged by trans pyridyl carboxylates of neighboring HCbdcp ligands to form a 1D chain (Figure 1b). Then, these chains are further bridged by another kind of chain along the $b$ axis containing cis carboxylates (Figure 1c) to propagate a 2D $(4,4)$ rhomboid grid network (Figure 1d,e). Within each layer, the rhomboid windows have dimensions of $9.53 \times 9.68 \AA^{2}$ with angles of $89.55^{\circ}$ and $90.45^{\circ}$ (defined by $\mathrm{Zn} \cdots \mathrm{Zn}$ distances and $\mathrm{Zn} \cdots \mathrm{Zn} \cdots \mathrm{Zn}$ angles). Because of the flexible methylene group, there are two kinds of dihedral angles between the two aromatic rings in $\mathrm{HCbdcp}^{-}$ligands $\left(60.15\right.$ and $\left.83.28^{\circ}\right)$. However, thanks to the protonated benzyl-COO groups being located only at the grids of the 2D network, such an angle has no influence on the final topology of complex 1. Moreover, just for the protonated benzyl-COO groups, adjacent layers are connected by various $\mathrm{O}-\mathrm{H} \cdots \mathrm{O}$ hydrogen bonds interactions between these groups and the deprotonated pyridyl-COO groups (Table S2) to generate the 3D supramolecular architecture of compound 1 (Figure 1f). 
(a)

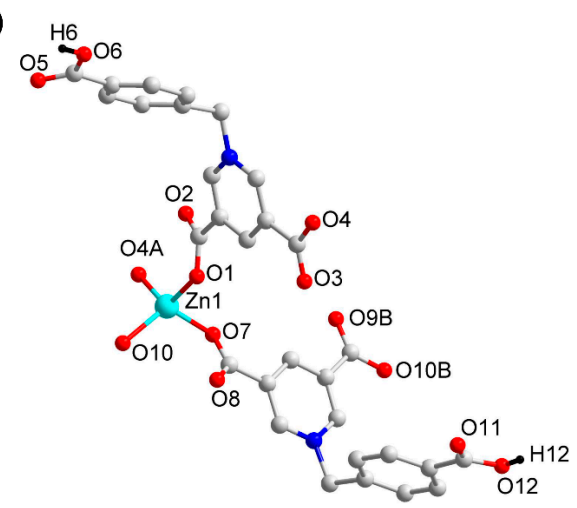

(b)

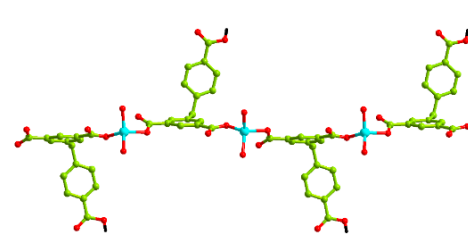

(c)

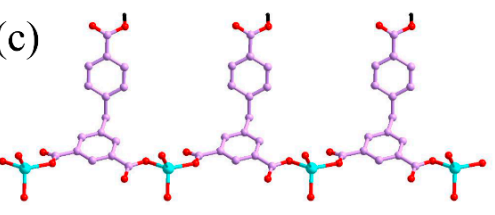

(e)

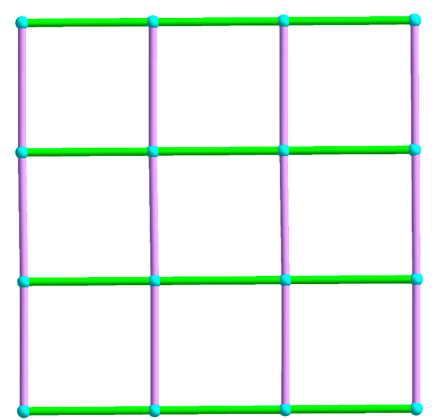

(d)

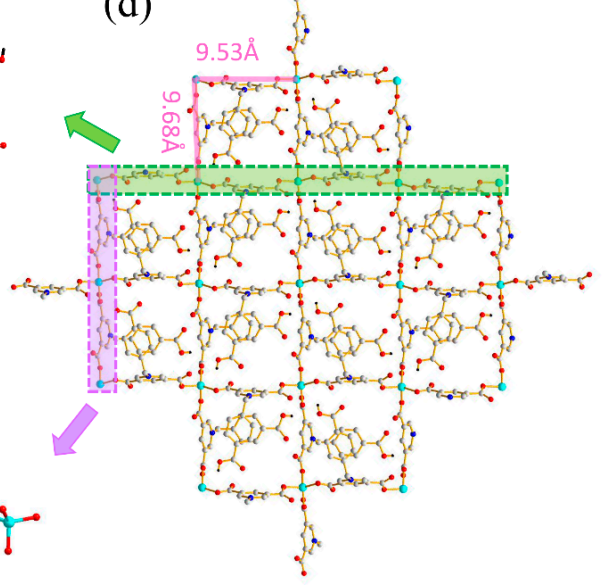

(f)

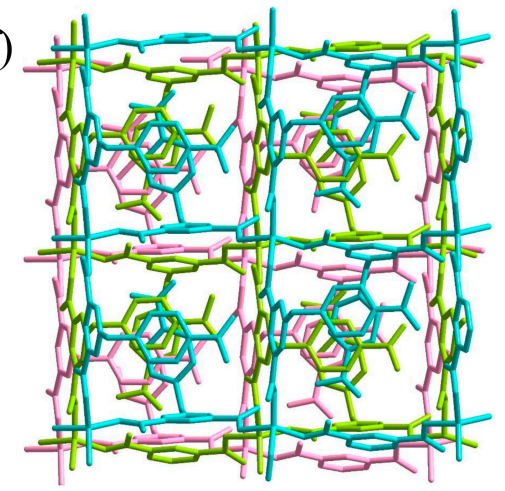

Figure 1. (a) Coordination environment of the metal atom and ligand of $\mathbf{1}$ (symmetry codes: (A) $x$, $\mathrm{y}-1, \mathrm{z}$; (B) $\mathrm{x}+1,-\mathrm{y}+1, \mathrm{z}+1 / 2$; (C) $\mathrm{x}, \mathrm{y}+1, \mathrm{z}$; (D) $\mathrm{x}-1,-\mathrm{y}+1, \mathrm{z}-1 / 2)$. (b) $1 \mathrm{D}$ chain generated by $\mathrm{Zn}$ (II) centers and trans $\mathrm{HCbdcp}^{-}$ligands. (c) 1D chain generated by Zn(II) centers and cis $\mathrm{HCbdcp}^{-}$ ligands. (d) The 2D network of 1 . (e) Topological representation of the 2D $(4,4)$ rhomboid grid network of $\mathbf{1}$. (f) The 3D supramolecular architecture of $\mathbf{1}$.

\subsubsection{Descriptions of the Crystal Structures of $\left\{[\mathrm{Mn}(\mathrm{Cbdcp})] \cdot 3 \mathrm{H}_{2} \mathrm{O}\right\}$ (2)}

Compound 2 belongs to the monoclinic $P 2_{1} / c$ space group and encompasses a $3 \mathrm{D}$ coordination network with a 6,6-connected-type topology. The asymmetric unit of 2 contains one crystallographically independent $\mathrm{Mn}(\mathrm{II})$ ion and one Cbdcp ${ }^{2-}$ ligand. Each $\mathrm{Mn}$ (II) ion is six-coordinated with oxygen atoms from six fully deprotonated $\mathrm{Cbdcp}^{2-}$ ligands, to conform to a distorted octahedral coordination geometry with the $\mathrm{Mn}-\mathrm{O}$ bond lengths varying from 2.145 (2) to 2.222(2) $\AA$ and the $\mathrm{O}-\mathrm{Mn}-\mathrm{O}$ bond angles falling in the ranges of $77.61(8)$ to $165.33(8)^{\circ}$ (Figure 2a); among them, four oxygen atoms-O1, 
$\mathrm{O} 2 \mathrm{~A}, \mathrm{O} 3 \mathrm{C}$ and $\mathrm{O} 4 \mathrm{D}-\mathrm{of}$ four carboxylates bound in bidentate bridging coordination fashion $\mu_{2}-\eta^{1} \eta^{1}$ in the equatorial plane, while the remaining two oxygen atoms (O5B and O6E) from another carboxylate, with the same coordination fashion, occupy the axial positions. As shown in Figure 2c, neighboring $\mathrm{Mn}(\mathrm{II})$ ions are linked together by sharing three bridging carboxylate $\left(\mathrm{COO}^{-}\right)$groups of three $\mathrm{Cbdcp}^{2-}$ ligands to form an infinite rod-like inorganic chain $\left\{\mathrm{Mn}\left(\mu_{2}-\mathrm{CO}_{2}\right)_{3}\right\}_{n}$, resulting in the Mn1 $\cdots \mathrm{Mn} 1 \mathrm{~A}$ distance of 4.1330(7) $\AA$ within it. Each rod-like chain contains triple-stranded helixes along the $c$ axis. Then, each 1D chain further connects to two neighboring chains through trans pyridine rings of bridging $\mathrm{Cbdcp}^{2-}$ ligands to form a sheet, with a 1D beaded chain along the $b$ axis. Furthermore, adjacent sheets are associated together through the methylene and benzene rings of $\mathrm{Cbdcp}^{2-}$ ligands to give rise to a 3D framework, in which the dihedral angle of the benzene ring and the pyridine ring is about $81.48^{\circ}$ (Figure $2 \mathrm{~b}$ ). The whole 3D structure can be simplified by topological depiction, and its topological analysis shows that complex 2 can be described as a 6,6-connected $\left\{4^{10} \cdot 6^{5}\right\}\left\{4^{7} \cdot 6^{6} \cdot 8^{2}\right\}$ topology (Figure 2d).

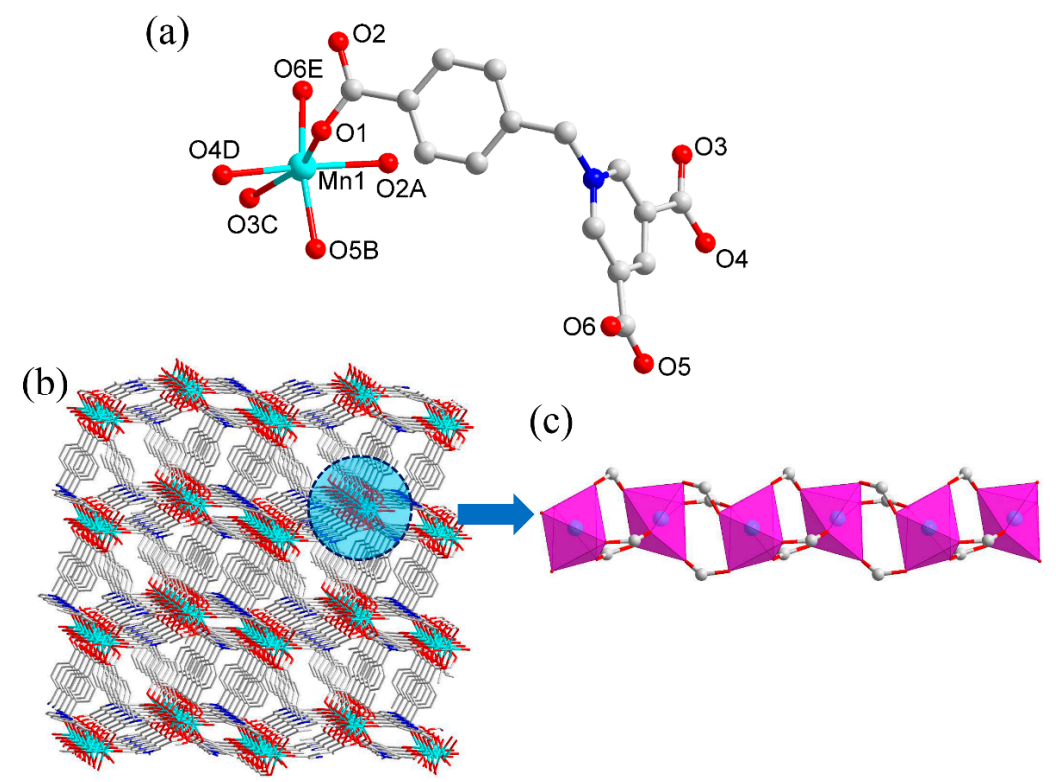

(d)

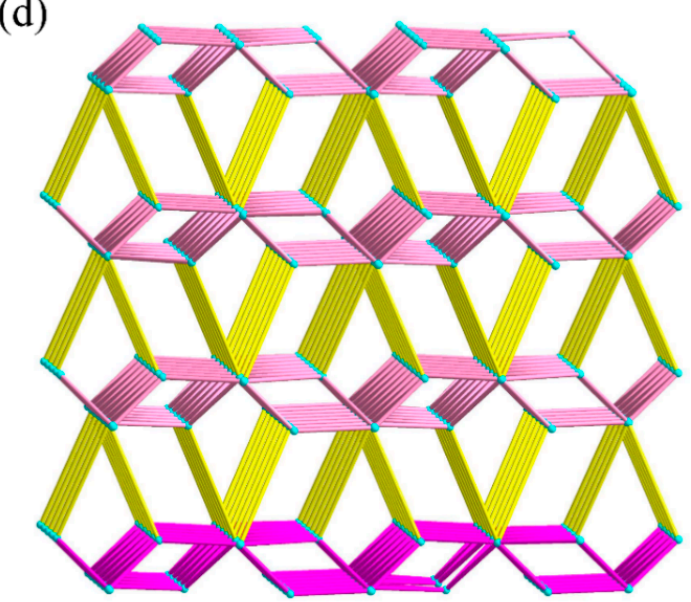

Figure 2. (a) Coordination environment of the metal atom and ligand of 2 (symmetry codes: (A) $x$, $-\mathrm{y}+1 / 2, \mathrm{z}+1 / 2 ;(B)-\mathrm{x}+1,-\mathrm{y}+1,-\mathrm{z}+1$; (C) $\mathrm{x}-1,-\mathrm{y}+1 / 2, \mathrm{z}-1 / 2 ;(\mathrm{D}) \mathrm{x}-1, \mathrm{y}, \mathrm{z}-1$; (E) $-\mathrm{x}+1, \mathrm{y}-1 / 2,-\mathrm{z}+1 / 2$; (F) $\mathrm{x},-\mathrm{y}+1 / 2, \mathrm{z}-1 / 2$; (G) $\mathrm{x}+1,-\mathrm{y}+1 / 2, \mathrm{z}+1 / 2 ;(\mathrm{H}) \mathrm{x}+1, \mathrm{y}$, $z+1$; (I) $-x+1, y+1 / 2,-z+1 / 2)$. (b) The 3D framework of 2 . (c) The infinite rod-like inorganic $\left\{\mathrm{Mn}\left(\mu_{2}-\mathrm{CO}_{2}\right)_{3}\right\}_{n}$ chain generated by $\mathrm{Mn}(\mathrm{II})$ and carboxylate groups of $\mathrm{Cbdcp}^{2-}$ ligands. (d) Topological representation of the 3D 6,6-connected $\left\{4^{10} .6^{5}\right\}\left\{4^{7} \cdot 6^{6} .8^{2}\right\}$ topology of 2 . 


\subsubsection{Descriptions of the Crystal Structures of $\left\{\left[\mathrm{Cu}_{2}(\mathrm{Cbdcp})(\mathrm{HCbdcp}) \mathrm{Cl} \cdot \mathrm{H}_{2} \mathrm{O}\right] \cdot 2 \mathrm{H}_{2} \mathrm{O}\right\}$ (3)}

$\mathrm{X}$-ray analysis on 3 revealed that this compound crystallizes in the triclinic space group $P-1$ and possesses a dinuclear 2D framework. As shown in Figure 3a, in the basic structural unit of 3, there are two independent $\mathrm{Cu}$ (II) ions, one completely deprotonated $\mathrm{Cbdcp}^{2-}$ ion, one partially deprotonated $\mathrm{HCbdcp}^{-}$ion, one coordinated $\mathrm{Cl}^{-}$ion, and one coordinated water molecule. Each $\mathrm{Cu} 1$ is located on the center of a distorted octahedron, whose equatorial plane consists of four oxygen atoms (O1, O5A, O7 and O8) of two $\mathrm{Cbdcp}^{2-}$ ligands and one $\mathrm{HCbdcp}^{-}$ligand, and whose axial positions were occupied by two oxygen atoms (O6A and O13), one coming from a Cbdcp ${ }^{2-}$ ligand and one from coordinated water, respectively. Each $\mathrm{Cu} 2$ atom displays a square pyramidal geometry with four oxygen atoms of two $\mathrm{Cbdcp}^{2-}$ ligands and two $\mathrm{HCbdcp}^{-}$ligands in the equatorial plane, while the $\mathrm{Cl}^{-}$ion occupies the apical position of the square pyramid. Two adjacent $\mathrm{Cu} 2$ ions are bridged by two pairs of carboxylates groups in bidentate bridging coordination mode to generate paddle-wheel dinuclear subunits $\left\{\mathrm{Cu}_{2}\left(\mu_{2}-\mathrm{CO}_{2}\right)_{4}\right\}$, with the $\mathrm{Cu} 2 \cdots \mathrm{Cu} 2 \mathrm{D}$ distance of 2.7357(11) $\AA$. The $\mathrm{Cu}-\mathrm{O}$ distances in 3 are in the range of 1.922(5) $-2.028(5) \AA$, and $\mathrm{Cu} 2-\mathrm{Cl} 1=2.376(3) \AA$.
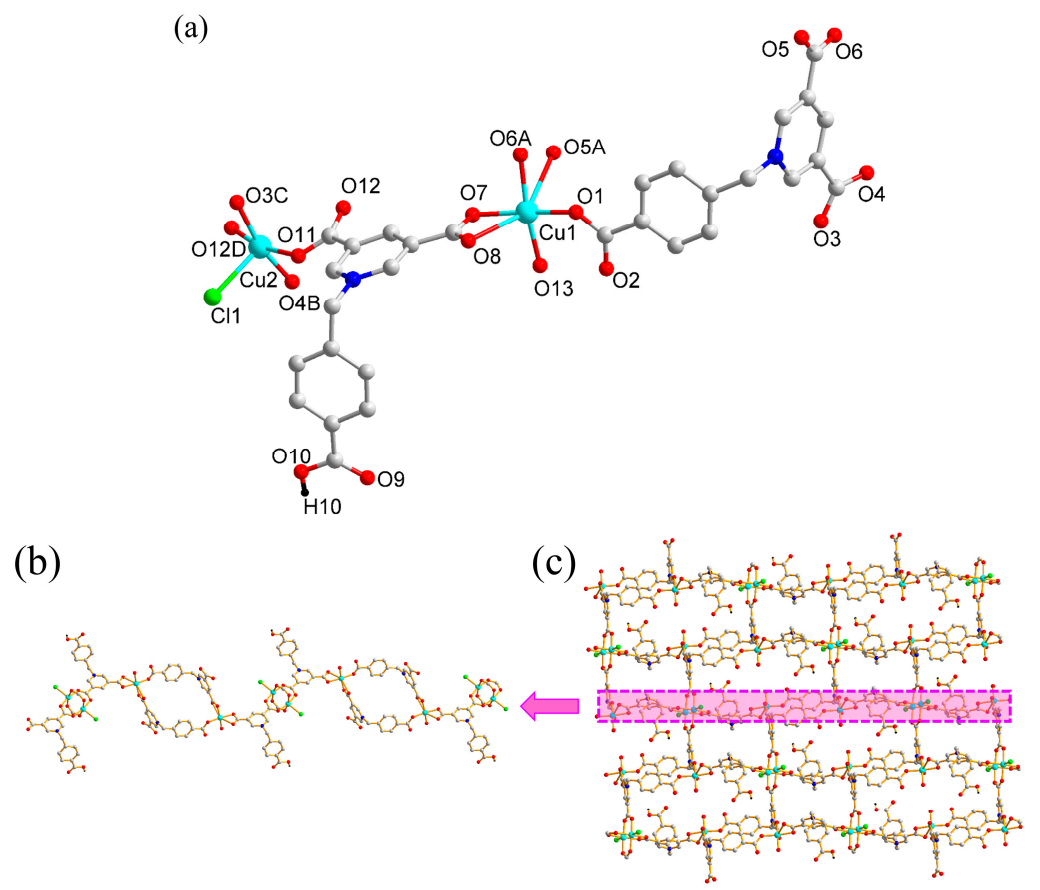

(d)

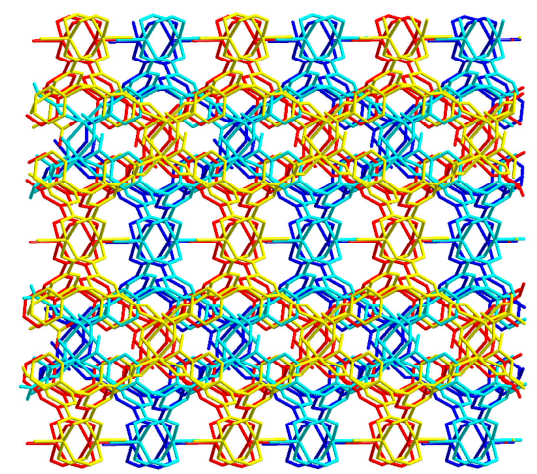

Figure 3. (a) Coordination environment of the metal atom and ligand of 3 (symmetry codes: (A) $-x$, $-\mathrm{y},-\mathrm{z}+1 ;(\mathrm{B})-\mathrm{x},-\mathrm{y}+1,-\mathrm{z}+1 ;(\mathrm{C}) \mathrm{x}+1, \mathrm{y}+1, \mathrm{z}-1 ;(\mathrm{D})-\mathrm{x}+1,-\mathrm{y}+2,-\mathrm{z} ;(\mathrm{E}) \mathrm{x}-1, \mathrm{y}-1, \mathrm{z}+1)$. (b) The 1D infinite loop chain in compound 3. (d) The 2D network of 3. (c) The 3D supramolecular architecture of 3. (d) Packing diagram in the space-filling model showing the 3D supramolecular architecture of 3 . 
In complex 3, not all the oxygen atoms in the carboxyl group of this kind of zwitterionic ligands are involved in coordination with the metal. Three carboxylate groups of the fully deprotonated $\mathrm{Cbdcp}^{2-}$ ligand adopt three coordination modes: one pyridyl-COO adopts a bidentate bridging coordination fashion $\mu_{2}-\eta^{1} \eta^{1}$, another pyridyl-COO shows a chelating bidentate coordination mode $\mu_{1}-\eta^{1} \eta^{1}$, and the remaining benzyl-COO show a monodentate coordination fashion $\mu_{1}-\eta^{1}$. There are two coordination modes for the two pyridyl-COO groups of the partly deprotonated HCbdcp ${ }^{-}$ ligand $\left(\mu_{2}-\eta^{1} \eta^{1}\right.$ and $\left.\mu_{1}-\eta^{1} \eta^{1}\right)$, and the free benzyl-COO group within it is protonated and does not connect with the metal centers. Two $\mathrm{Cu} 1$ ions link two $\mathrm{Cbdcp}^{2-}$ ligands in the trans conformation into a window with approximate dimensions of $7.42 \times 8.31 \AA^{2}$ and the dihedral angle of the benzene ring and the pyridine ring is about $72.00^{\circ}$, which are further connected through another two trans HCbdcp ${ }^{-}$ligands and the $\left\{\mathrm{Cu}_{2}\left(\mu_{2}-\mathrm{CO}_{2}\right)_{4}\right\}$ dimers to produce a one-dimensional (1D) infinite loop chain (Figure $3 \mathrm{~b})$. The $\left\{\mathrm{Cu}_{2}\left(\mu_{2}-\mathrm{CO}_{2}\right)_{4}\right\}$ dimers in this chain were further linked to the windows of another chain by $\mu_{2}-\eta^{1} \eta^{1}$ carboxylate groups of $\mathrm{Cbdcp}^{2-}$ ligands to form a dinuclear $2 \mathrm{D}$ framework with grids (Figure 3c). Thanks to the interlayer $\pi \cdots \pi$ stacking interactions between the neighboring benzene rings of two contiguous layers (centroid-centroid: $4.236 \AA$ ), the 3D supramolecular architecture of compound 3 is achieved (Figure 3d).

\subsubsection{Comparison of Complexes 1-3}

As discussed above, complexes 1-3 were all synthesized by the similar hydrothermal method, however, when the flexible multi-carboxylate linker $\mathrm{H}_{3} \mathrm{CbdcpCl}$ and different metal salts are involved in the construction, the final coordination polymers exhibit various framework structures: a mononuclear 2D $4^{4}$-sql network for 1, a 3D 6,6-connected-type topology for 2 and a novel dinuclear 2D layer for 3 . This phenomenon may be the result of many factors such as metal ion coordination geometry, coordination modes of carboxylate groups, hydrogen bonds and $\pi \cdots \pi$ stacking interactions. First of all, the tricarboxylate ligand $\mathrm{H}_{3} \mathrm{CbdcpCl}$ with different geometry and binding fashions is undoubtedly a significant factor influencing the final structures (Scheme 1). For compound $1, \mathrm{H}_{3} \mathrm{CbdcpCl}$ only has one kind of form, in which two deprotonated pyridyl-COO were in $\mu_{1}-\eta^{1}$ coordination mode to connect with $\mathrm{Zn}$ (II) ions and the protonated benzyl-COO group did not participate in the coordination. Just for the existence of protonated benzyl-COO groups, one $\mathrm{H}_{3} \mathrm{CbdcpCl}$ alone can bridge two adjacent $\mathrm{Zn}$ (II) centers to form a 2D $(4,4)$ rhomboid grid network with $\mathrm{Zn} \cdots \mathrm{Zn} \cdots \mathrm{Zn}$ angles of $89.55^{\circ}$ and $90.45^{\circ}$. For $2, \mathrm{H}_{3} \mathrm{CbdcpCl}$ also only has one kind of form. However, different from $\mathbf{1}$ is that all the three carboxylate groups were fully deprotonated and are all in $\mu_{2}-\eta^{1} \eta^{1}$ coordination fashion. Thus, one $\mathrm{H}_{3} \mathrm{CbdcpCl}$ can link three $\mathrm{Mn}$ (II) ions locating in different directions to produce a 3D structure. Compared with $\mathbf{1}$ and 2, there are two kinds of $\mathrm{H}_{3} \mathrm{CbdcpCl}$ in 3. One was fully deprotonated to form $\mathrm{Cbdcp}^{2-}$, and the three carboxylate groups adopt three coordination fashions $\left(\mu_{2}-\eta^{1} \eta^{1}, \mu_{1}-\eta^{1} \eta^{1}\right.$, and $\left.\mu_{1}-\eta^{1}\right)$ to connect neighboring $\mathrm{Cu}$ (II) ions and $\left\{\mathrm{Cu}_{2}\left(\mu_{2}-\mathrm{CO}_{2}\right)_{4}\right\}$ dimers to get a 1D loop chain. Another $\mathrm{H}_{3} \mathrm{CbdcpCl}$ is similar to that of $\mathbf{1}$; just the two pyridyl-COO groups are deprotonated, but unlike 1, the two pyridyl-COO groups in 3 take two coordination modes $\left(\mu_{2}-\eta^{1} \eta^{1}\right.$ and $\left.\mu_{1}-\eta^{1} \eta^{1}\right)$ to join connected chains to get a 2D layer. Secondly, the introduction of a rotationally flexible methylene linker in fully deprotonated $\mathrm{H}_{3} \mathrm{CbdcpCl}$ also supports a variety of products. The v-shaped flexible ligand, $\mathrm{Cbdcp}^{2-}$, can adopt different dihedral angles of the benzene ring and the pyridine ring around the methylene according to the geometric needs of the different structures. The dihedral angles of $81.48^{\circ}$ in 2 and $72.00^{\circ}$ in 3 result in the loop structures of $\mathbf{2}$ and $\mathbf{3}$. Additionally, different metal centers definitely influence the molecular structures. Four-coordinated $\mathrm{Zn}$ (II) ions restrict 1 to generate a high dimension and a complicated framework. Six-coordinated $\mathrm{Mn}$ (II) ions, six-coordinated $\mathrm{Cu} 1$ ions and five-coordinated $\mathrm{Cu} 2$ atoms are favorable to the 3D structure of 2 and the interesting novel dinuclear 2D structure of 3, respectively. Lastly, hydrogen bonds and $\pi \cdots \pi$ stacking interactions help compound 2 and 3 to achieve their 3D supramolecular architectures. Thus, we could synthesize target coordination polymers for functional materials by modulating the functional groups on the ligand and the metal centers. 


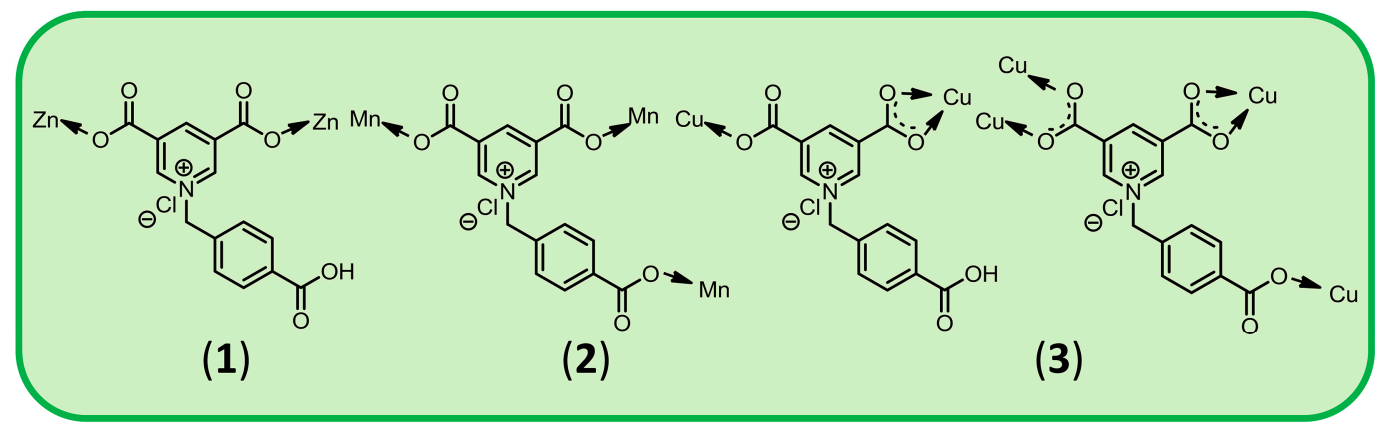

Scheme 1. Different coordination modes of the ligand; (1) for compound 1, (2) for compound 2 and (3) compound 3, respectively.

\subsection{Thermogravimetric and PXRD Analysis}

\subsubsection{Thermogravimetric Analysis}

To study the thermal stability of the compounds, thermal gravimetric analysis (TGA) of compounds 1-3 was performed under nitrogen atmosphere from room temperature to $800{ }^{\circ} \mathrm{C}$ with a heating rate of $10^{\circ} \mathrm{C} \cdot \mathrm{min}^{-1}$. The thermal curves are exhibited in Figure S1. The TGA curve for compound 1 displays that in the range from 60 to $158^{\circ} \mathrm{C}$, there was a weight loss of $2.9 \%$ owing to the release of water molecules (calcd: $2.63 \%$ ). The organic spacers then decompose after $286.9^{\circ} \mathrm{C}$. Compound 2 underwent loss of its water molecules between 70 and $201{ }^{\circ} \mathrm{C}$ with a mass loss of $13.6 \%$ (calcd: $13.23 \%$ ), then ligand combustion occurred above $363^{\circ} \mathrm{C}$. The TGA curve of 3 shows the weight loss of $6.9 \%$ between 70 and $231{ }^{\circ} \mathrm{C}$, corresponding to the loss of three water molecules (calcd: $6.62 \%$ ), which is also followed by the organic components' breakdown after $383{ }^{\circ} \mathrm{C}$ [23].

\subsubsection{PXRD Analysis}

To determine whether the crystal structures are truly representative of the bulk materials tested in property studies, powder X-ray diffraction (PXRD) experiments were carried out for compounds 1-3. The PXRD experimental and as-simulated patterns of compounds 1-3 are shown in the Supporting Information (Figures S2-S4). The peak positions of the bulk synthesized materials and the measured single crystals for 1-3 are in good agreement with each other, indicating that the crystal structures are truly representative of the bulk crystal products. The differences in intensity may be owing to the preferred orientation of the crystal samples.

\subsection{Solid-State Luminescence of $\mathbf{1}-\mathbf{3}$}

The solid-state photoluminescence properties of $\mathrm{H}_{3} \mathrm{CbdcpCl}$ and complexes 1-3 have been investigated at room temperature. As shown in Figure 4, excitation of the solid samples of the ligand $\mathrm{H}_{3} \mathrm{CbdcpCl}$ at $355 \mathrm{~nm}$ produces a broad fluorescence emission band with a maximum at $509 \mathrm{~nm}$, which may be attributed to the $\pi^{*}-n$ or $\pi^{*}-\pi$ transitions within the conjugated ligand. Excitation of the microcrystalline sample of 1 at $355 \mathrm{~nm}$ produced intense luminescence with the peak maxima at $394 \mathrm{~nm}$ that is blue-shifted about $115 \mathrm{~nm}$ with a decrease in luminescence intensity compared with that of the ligand $\mathrm{H}_{3} \mathrm{CbdcpCl}$. The large blue shift is probably because of the intraligand and ligand-to-metal charge transfer [23]. The slight reduction of luminescence may be ascribed to the decrease of the conjugation degree and the increase of the loss of energy by radiationless decay. As for complexes 2 and 3, no clear photoluminescence was observed. The luminescence emissions are probably quenched by the $\mathrm{Mn}$ (II) and $\mathrm{Cu}(\mathrm{II})$ ions, when excited at $350 \mathrm{~nm}$ for 2 and $348 \mathrm{~nm}$ for 3 respectively, which may be a result of the $\mathrm{d}-\mathrm{d}$ transitions of unfilled d-orbitals of $\mathrm{Mn}(\mathrm{II})$ and $\mathrm{Cu}(\mathrm{II})$ ions [24,25]. 


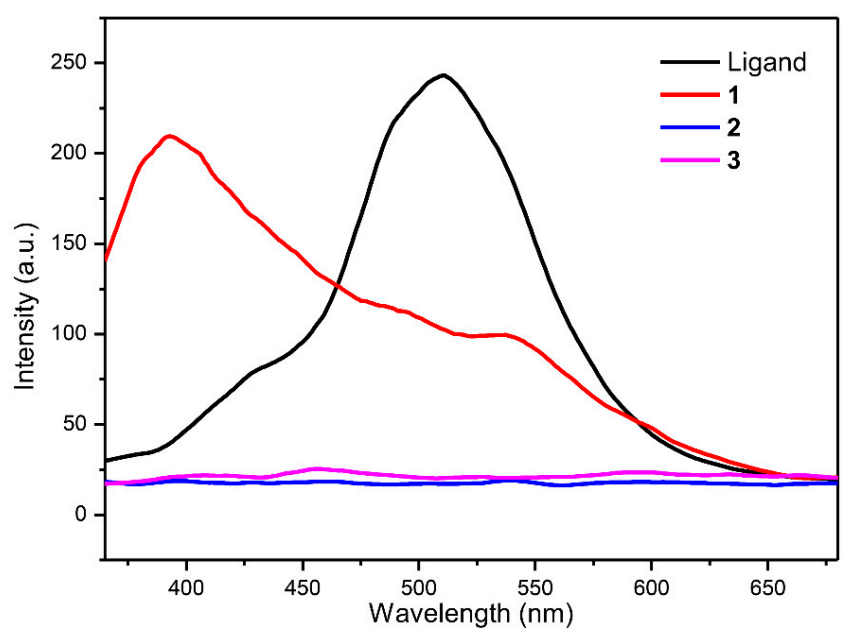

Figure 4. The solid-state photoluminescence properties of the ligand and complexes 1-3 at room temperature.

\subsection{Magnetic Properties for $\mathbf{2}$ and $\mathbf{3}$}

Variable-temperature magnetic susceptibility measurements were performed on powdered crystalline samples of complexes 2 and 3 in the 2-300 K temperature range with an applied magnetic field of 1000 Oe. The obtained data, $\chi_{\mathrm{M}}, \chi_{\mathrm{M}} T$ and $\chi_{\mathrm{M}}{ }^{-1}$ (inset) vs. $T$ plot is shown in Figures $5 \mathrm{a}$ and 6a, confirming the predominant antiferromagnetic interactions in both compounds. For compound 2, the room temperature $\chi_{\mathrm{M}} T$ value is $17.38 \mathrm{~cm}^{3} \cdot \mathrm{K} \cdot \mathrm{mol}^{-1}$, which is much higher than the spin-only value of $13.12 \mathrm{~cm}^{3} \cdot \mathrm{K} \cdot \mathrm{mol}^{-1}$ expected for three magnetically isolated high-spin $\mathrm{Mn}$ (II) ions ( $\left.\mathrm{S}=5 / 2\right)$ considering $g=2.00$. During cooling, the value of $\chi_{\mathrm{M}} T$ continues to slowly decrease until near $90 \mathrm{~K}$; below this temperature, the $\chi_{\mathrm{M}} T$ value decreases sharply to $1.22 \mathrm{~cm}^{3} \cdot \mathrm{K} \cdot \mathrm{mol}^{-1}$ at $2 \mathrm{~K}$, suggesting antiferromagnetic behavior. In addition, the appearance of a round peak at $7 \mathrm{~K}$ in the $\chi_{\mathrm{M}} \mathrm{vs}$. $T$ curve indicates antiferromagnetic ordering. The magnetic susceptibility data in the temperature range of 10-300 K can be well fitted to the Curie-Weiss law $\chi_{\mathrm{M}}=C /(T-\theta)$, with a Curie constant $C$ value of $18.21 \mathrm{~cm}^{3} \cdot \mathrm{K} \cdot \mathrm{mol}^{-1}$ and a Weiss temperature $\theta$ of $-13.66 \mathrm{~K}$, which further confirms an overall antiferromagnetic exchange interaction between the $\mathrm{Mn}(\mathrm{II})$ ions throughout the framework (Figure 5a).
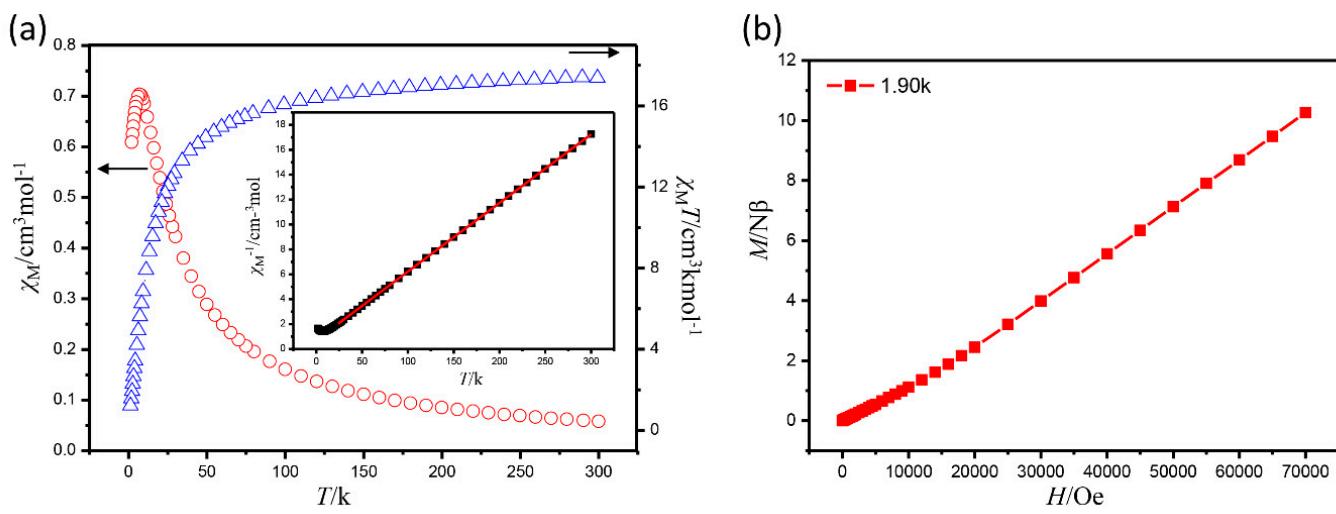

Figure 5. (a) Temperature dependence of $\chi_{M} T(\Delta), \chi_{M}(\bigcirc)$, and $\chi_{M}{ }^{-1}$ ( $\square$, inset) for compound 2 with an applied field of 1000 Oe. The solid line corresponds to the theoretical fit of the Curie-Weiss law $\chi_{M}=C /(T-\theta)$. (b) Field dependence of magnetization for 2 at $2 \mathrm{~K}$.

For compound 3, the room temperature $\chi_{\mathrm{M}} T$ value is $1.86 \mathrm{~cm}^{3} \cdot \mathrm{K} \cdot \mathrm{mol}^{-1}$, which is much lower than the expected spin-only value of 2.25 for six isolated $\mathrm{S}=1 / 2 \mathrm{Cu}$ (II) ions with $\mathrm{g}=2.00$. During cooling, the value of $\chi_{\mathrm{M}} T$ steadily decreases to reach the value of $0.91 \mathrm{~cm}^{3} \cdot \mathrm{K} \cdot \mathrm{mol}^{-1}$ at $2 \mathrm{~K}$, which is a little 
higher than the spin-only value $\left(0.75 \mathrm{~cm}^{3} \cdot \mathrm{K} \cdot \mathrm{mol}^{-1}\right)$ for two non-interacting $\mathrm{S}=1 / 2 \mathrm{Cu}$ (II) spin carriers. This phenomenon indicates the overall antiferromagnetic behavior in $\mathbf{3}$ and these antiferromagnetic couplings between $\mathrm{Cu}(\mathrm{II})$ ions lead to an $\mathrm{S}=1$ spin ground state at low temperature. Fitting $\chi_{\mathrm{M}}$ data in the range $120-300 \mathrm{~K}$ with the Curie-Weiss law gives a Curie constant $C=3.01 \mathrm{~cm}^{3} \cdot \mathrm{K} \cdot \mathrm{mol}^{-1}$ and a negative Weiss temperature $\theta$ of $-187.35 \mathrm{~K}$. The high value of $C$ and the negative $\theta$, which may be partly contributed to by the strong spin-orbit coupling, further confirm an overall antiferromagnetic exchange interaction between the $\mathrm{Cu}(\mathrm{II})$ ions throughout the framework (Figure 6a).

To probe the low-temperature magnetic properties of 2 and 3, isothermal field-dependent magnetizations $M(\mathrm{H})$ for 2 and 3 were measured in $1.9 \mathrm{~K}$. The magnetization value of 2 showed a gradual increase of the magnetization at the whole field and reached $10.26 \mathrm{~N} \beta$ at $1.9 \mathrm{~K}$ and $70 \mathrm{kOe}$, which is far from the saturated values, confirming the significant antiferromagnetic interactions within it (Figure 5b). Compound 3 exhibited a rapid increase of the magnetization at low field followed by a slow linear increase at high field and reached $2.22 \mathrm{~N} \beta$ at $1.9 \mathrm{~K}$ and $70 \mathrm{kOe}$, which is close to the saturation value of $2.00 \mathrm{~N} \beta$ for an $\mathrm{S}=1$ spin ground state at high field (Figure $6 \mathrm{~b}$ ).
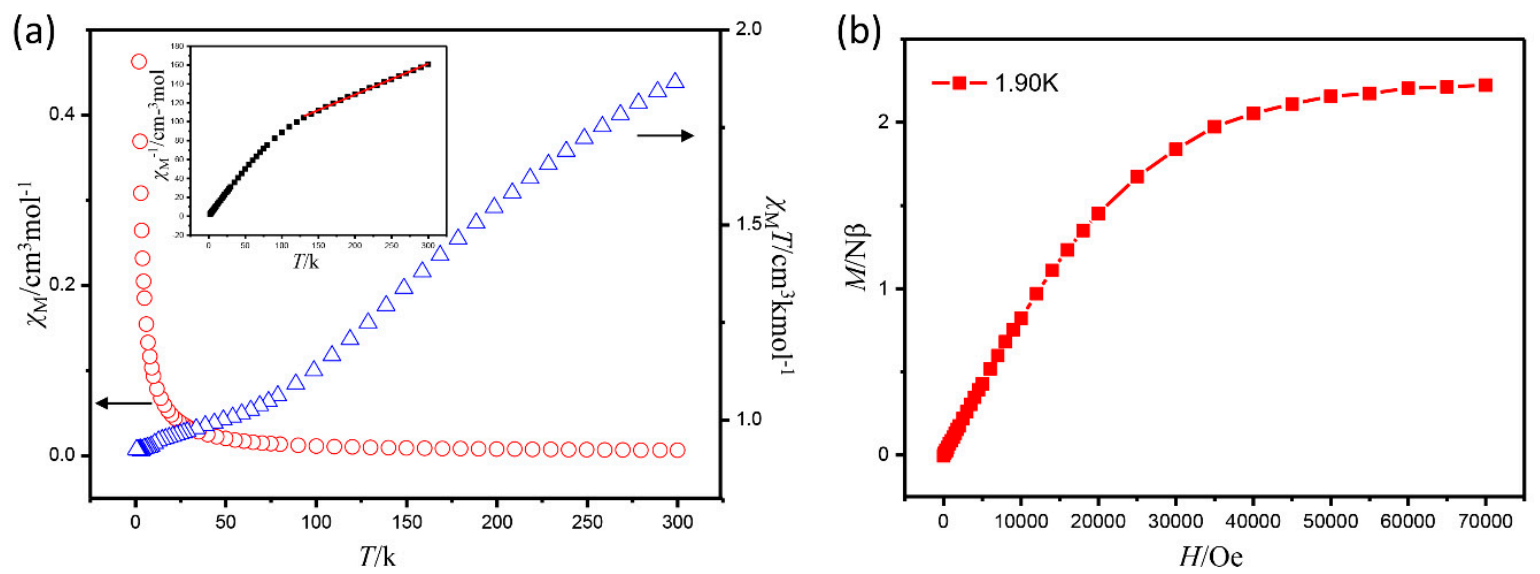

Figure 6. (a) Temperature dependence of $\chi_{M} T(\Delta), \chi_{M}(\bigcirc)$, and $\chi_{M}^{-1}$ ( $\square$, inset) for compound 3 with an applied field of 1000 Oe. The solid line corresponds to the theoretical fit of the Curie-Weiss law $\chi_{M}=C /(T-\theta)$. (b) Field dependence of magnetization for 3 at $2 \mathrm{~K}$.

\section{Experimental Section}

\subsection{Material and Methods}

All of the reagents and solvents used in this paper were purchased from Adamas-beta Corporation Limited (Shanghai, China) and used as received without further purification, unless otherwise indicated. The 3,5-dicarboxy-1-(4-carboxybenzyl)pyridin-1-ium chloride $\left(\mathrm{H}_{3} \mathrm{CbdcpCl}\right)$ was synthesized according to a previously reported procedure [26,27]. The NMR spectra were recorded on a Bruker DRX400 (Bruker, Billerica, MA, USA) $\left({ }^{1} \mathrm{H}: 400 \mathrm{MH}_{\mathrm{Z}},{ }^{13} \mathrm{C}: 100 \mathrm{MH}_{\mathrm{Z}}\right)$, chemical shifts $(\delta)$ are expressed in ppm, and $J$ values are given in $\mathrm{Hz}$, and deuterated DMSO was used as solvent. IR spectra were recorded on a FT-IR Thermo Nicolet Avatar 360 (Thermo, Waltham, MA, USA) using KBr pellet. The phase purity of the samples was investigated by powder X-ray diffraction (PXRD) measurements carried out on a Bruker D8-Advance diffractometer (Bruker, Munich, Germany) equipped with CuK $\alpha$ radiation $(\lambda=1.5406 \AA)$ at a scan speed of $1^{\circ} / \mathrm{min}$. Thermal stability studies were carried out on a NETSCHZ STA-449C thermoanalyzer (NETSCHZ, Bavaria, Germany) with a heating rate of $10^{\circ} \mathrm{C} / \mathrm{min}$ under a nitrogen atmosphere. All fluorescence measurements were performed on an Edinburgh Instrument F920 spectrometer (Edinburgh, Livingston, UK). Variable-temperature susceptibility measurements of crystalline samples were performed on a Quantum Design MPMS-XL SQUID magnetometer (Quantum, Waltham, MA, USA). 


\subsection{Synthetic Procedures}

\subsubsection{Synthesis of 3,5-Dicarboxy-1-(4-carboxybenzyl)pyridin-1-ium Chloride $\left(\mathrm{H}_{3} \mathrm{CbdcpCl}\right)$}

A mixture of 4-(chloromethyl)benzoic acid (1.705 g, $10 \mathrm{mmol})$ and 3,5-pyridinedicarboxylic acid $(1.670 \mathrm{~g}, 10 \mathrm{mmol})$ in DMF $(50 \mathrm{~mL})$ was stirred at $100{ }^{\circ} \mathrm{C}$ for $72 \mathrm{~h}$. After the mixture was cooled down to room temperature, the white precipitate formed were collected by filtration and washed with acetone $(20 \mathrm{~mL} \times 3)$ to afford $\mathrm{H}_{3} \mathrm{CbdcpCl}(3.14 \mathrm{~g}, 95 \%)$ which was identical to data in the literature [26,27]. ${ }^{1} \mathrm{H}$ NMR (400 Hz, DMSO-d6): $\delta=9.90(\mathrm{~s}, 2 \mathrm{H}, \mathrm{ArH}), 9.12(\mathrm{~s}, 1 \mathrm{H}, \mathrm{ArH}), 7.99(\mathrm{~d}, 2 \mathrm{H}, \mathrm{ArH}, J=8.4 \mathrm{~Hz})$, $7.70(\mathrm{~d}, 2 \mathrm{H}, \mathrm{ArH}, J=8.4 \mathrm{~Hz}), 6.17\left(\mathrm{~s}, 2 \mathrm{H}, \mathrm{CH}_{2}\right) ;{ }^{13} \mathrm{C}$ NMR $(100 \mathrm{~Hz}, \mathrm{DMSO}-d 6): \delta=167.2,162.9,149.2$, 145.3, 138.9, 132.5, 132.1, 130.4, 129.6, 63.4. (Figure S5) Main IR $\left(\mathrm{KBr}, \mathrm{cm}^{-1}\right)$ : 3554, 3021, 1944, 1719, 1398, 1329, 1403, 1229, 1181 (Figure S6). Melting point: $345-346^{\circ} \mathrm{C}$. Anal. Calcd. for $\mathrm{C}_{15} \mathrm{H}_{12} \mathrm{NO}_{6} \mathrm{Cl}$ : C 53.35, H 3.58, N 4.15. Found: C 53.29, H 3.52, N 4.11.

\subsubsection{Synthesis of $\left\{\left[\mathrm{Zn}(\mathrm{HCbdcp})_{2}\right] \cdot \mathrm{H}_{2} \mathrm{O}\right\}(\mathbf{1})$}

$\mathrm{ZnCl}_{2}(0.05 \mathrm{mmol}), \mathrm{H}_{3} \mathrm{CbdcpCl}(0.05 \mathrm{mmol}), \mathrm{NaOH}(0.3 \mathrm{mmol})$ and $\mathrm{H}_{2} \mathrm{O}(10 \mathrm{~mL})$ were added to a $15 \mathrm{~mL}$ Telfon-lined stainless steel autoclave, and the solution was heated at $90{ }^{\circ} \mathrm{C}$ for $48 \mathrm{~h}$, after having been stirred for $10 \mathrm{~min}$ at room temperature. Then, the mixture was cooled down to room temperature at a rate of $5{ }^{\circ} \mathrm{C} / \mathrm{h}$. Colourless block crystals of the product were collected by filtration and washed with water several times, and dried in air. The obtained yield based on the $\mathrm{H}_{3} \mathrm{CbdcpCl}$ was $64.3 \%$. Main IR (KBr, cm $\left.{ }^{-1}\right)$ : 3492, 3067, 1720, 1646, 1362, 1225, 937, 734 (Figure S6). Anal. Calcd. for $\mathrm{C}_{30} \mathrm{H}_{22} \mathrm{~N}_{2} \mathrm{O}_{13} \mathrm{Zn}$ : C 52.69, H 3.24, N 4.10. Found: C 52.48, H 3.46, N 4.06.

\subsubsection{Synthesis of $\left\{[\mathrm{Mn}(\mathrm{Cbdcp})] \cdot \mathrm{H}_{2} \mathrm{O}\right\}(2)$}

Complex 2 was also synthesized by the same method, except that $\mathrm{Mn}\left(\mathrm{NO}_{3}\right)_{2} \cdot 4 \mathrm{H}_{2} \mathrm{O}(0.05 \mathrm{mmol})$ was used instead of $\mathrm{ZnCl}_{2}(0.05 \mathrm{mmol})$. Yellow needle-like crystals of complex 2 were collected by heating the complex at $90^{\circ} \mathrm{C}$ for $48 \mathrm{~h}$, filtration and washing with water several times, and drying in air. The obtained yield based on the $\mathrm{H}_{3} \mathrm{CbdcpCl}$ was $33.7 \%$. Main IR $\left(\mathrm{KBr}, \mathrm{cm}^{-1}\right)$ : 3445, 2998, 1651, 1601, 1380, 1099, 770, 717 (Figure S6). Anal. Calcd. for $\mathrm{C}_{15} \mathrm{H}_{11} \mathrm{NO}_{7} \mathrm{Mn}$ : C 48.41, H 2.98, N 3.76. Found: C $48.36, \mathrm{H} 3.02, \mathrm{~N} 3.71$.

\subsubsection{Synthesis of $\left\{\left[\mathrm{Cu}_{2}(\mathrm{Cbdcp})(\mathrm{HCbdcp}) \mathrm{Cl} \cdot \mathrm{H}_{2} \mathrm{O}\right] \cdot \mathrm{H}_{2} \mathrm{O}\right\}$ (3)}

The same synthetic method as that for $\mathbf{1}$ and $\mathbf{2}$ was used for $\mathbf{3}$, except that $\mathrm{CuCl}_{2} \cdot 2 \mathrm{H}_{2} \mathrm{O}(0.05 \mathrm{mmol})$ was used instead of $\mathrm{ZnCl}_{2}$ and $\mathrm{Mn}\left(\mathrm{NO}_{3}\right)_{2} \cdot 4 \mathrm{H}_{2} \mathrm{O}(0.05 \mathrm{mmol})$. Green block crystals of the product were collected by filtration and washed with water several times, and dried in air. The obtained yield based on the $\mathrm{H}_{3} \mathrm{CbdcpCl}$ was 53.1\%. Main IR $\left(\mathrm{KBr}, \mathrm{cm}^{-1}\right)$ : 3422, 1661, 1600, 1387, 736, 656, 553 (Figure S6). Anal. Calcd. for $\mathrm{C}_{30} \mathrm{H}_{23} \mathrm{ClCu}_{2} \mathrm{~N}_{2} \mathrm{O}_{14}$ : C 45.15, H 2.90, N 3.51. Found: C 45.06, H 2.98, N 3.47.

\subsection{Crystallography}

The selected single crystal with suitable dimensions was mounted on a glass fiber and used for X-ray diffraction analyses. Crystallographic data were collected at $296 \mathrm{~K}$ on a Bruker Smart AXS CCD diffractometer (Bruker, Munich, Germany) with graphite-monochromated MoK $\alpha$ radiation $(\lambda=0.71073 \AA)$ using the $\omega$-scan technique. Cell parameters were retrieved using SMART software and refined with SAINT on all observed reflections. Absorption corrections were applied with the program SADABS. Structures 1-3 were solved by direct methods using SHELXS-2014/7 and refined on F2 by full-matrix least-squares procedures. All nonhydrogen atoms were located in different Fourier syntheses and finally refined with anisotropic displacement parameters. Hydrogen atoms attached to the organic moieties were either located from the difference Fourier map or fixed stereochemically. In $\mathbf{2}$ and $\mathbf{3}$, the guest molecules within the pores of the framework are extremely distorted and cannot be satisfactorily modeled. Therefore, the SQUEEZE routine was added to the CIF file. The final chemical 
formula was estimated from the SQUEEZE results. Details of the crystallographic data collection and refinement parameters are summarized in Table 1. Main bond lengths and angles are presented in Tables S1 and S2 in the Supporting Information.

Table 1. Crystal data and structure refinement for 1-3.

\begin{tabular}{|c|c|c|c|}
\hline Compound Reference & 1 & 2 & 3 \\
\hline Chemical formula & $\mathrm{C}_{30} \mathrm{H}_{22} \mathrm{~N}_{2} \mathrm{O}_{13} \mathrm{Zn}$ & $\mathrm{C}_{15} \mathrm{H}_{9} \mathrm{NO}_{6} \mathrm{Mn}$ & $\mathrm{C}_{30} \mathrm{H}_{21} \mathrm{ClCu}_{2} \mathrm{~N}_{2} \mathrm{O}_{13}$ \\
\hline Formula Mass & 683.86 & 354.17 & 780.02 \\
\hline Crystal system & Monoclinic & Monoclinic & Triclinic \\
\hline$a / \AA$ & $10.8181(8)$ & $11.0574(11)$ & $8.3866(10)$ \\
\hline$b / \AA$ & $9.6825(7)$ & 17.0375(17) & $13.7642(17)$ \\
\hline$c / \AA$ & $15.1904(8)$ & $7.9534(8)$ & $16.359(2)$ \\
\hline$\alpha /^{\circ}$ & 90 & 90 & $71.192(2)$ \\
\hline$\beta /^{\circ}$ & $120.728(4)$ & $102.905(2)$ & $78.549(2)$ \\
\hline$\gamma /{ }^{\circ}$ & 90 & 90 & $75.018(2)$ \\
\hline Unit cell volume $/ \AA^{3}$ & $1367.75(17)$ & $1460.5(3)$ & $1713.1(4)$ \\
\hline Temperature/K & 296(2) & $296(2)$ & $296(2)$ \\
\hline Space group & $P_{C}$ & $P 2_{1} / c$ & $P \bar{\imath}$ \\
\hline$Z^{-1}$ & 2 & 4 & 2 \\
\hline Radiation type & $\operatorname{MoK} \alpha$ & $\operatorname{MoK} \alpha$ & $\operatorname{MoK} \alpha$ \\
\hline Absorption coefficient, $\mu / \mathrm{mm}^{-1}$ & 0.977 & 0.935 & 1.384 \\
\hline No. of reflections measured & 14462 & 13637 & 13940 \\
\hline No. of independent reflections & 6805 & 3353 & 6222 \\
\hline$R_{\text {int }}$ & 0.0597 & 0.0227 & 0.0506 \\
\hline Final $R_{1}$ values $(I>2 \sigma(I))$ & 0.0301 & 0.0443 & 0.0655 \\
\hline Final $w R\left(F^{2}\right)$ values $(I>2 \sigma(I))$ & 0.0801 & 0.1086 & 0.1871 \\
\hline Final $R_{1}$ values (all data) & 0.0353 & 0.0449 & 0.0965 \\
\hline Final $w R\left(F^{2}\right)$ values (all data) & 0.1032 & 0.1088 & 0.2191 \\
\hline Goodness of fit on $F^{2}$ & 1.127 & 1.279 & 1.009 \\
\hline
\end{tabular}

\section{Conclusions}

In summary, a series of interesting functional coordination polymers have been successfully designed and studied, by the use of the zwitterionic ligand $\mathrm{H}_{3} \mathrm{CbdcpCl}$ and different metal ions. Thanks to the different metal ions and the various coordination modes or the rotationally flexible $\mathrm{CH}_{2}$ linker in $\mathrm{H}_{3} \mathrm{CbdcpCl}$, these complexes show diverse frameworks. The solid-state photoluminescence properties of complexes 1-3 were studied, which show $\mathbf{1}$ emission maxima with blue-shift, and 2 or 3 emissions are quenched compared to $\mathrm{H}_{3} \mathrm{CbdcpCl}$. Magnetic studies of $\mathbf{2}$ and $\mathbf{3}$ show their overall antiferromagnetic behaviors. All the results demonstrated that the rotationally flexible multicarboxylate $\mathrm{H}_{3} \mathrm{CbdcpCl}$ ligand, together with different d-block metals, may realize various architectures and the functionalization of these materials. Further investigations are ongoing in our lab.

Supplementary Materials: The following are available online at www.mdpi.com/2073-4352/7/1/32/s1, Figure S1: The TGA curves of compounds 1-3, Figure S2: The PXRD experimental and as-simulated patterns of compound 1, Figure S3: The PXRD experimental and as-simulated patterns of compound 2, Figure S4: The PXRD experimental and as-simulated patterns of compound 3, Figure S5: ${ }^{1} \mathrm{H}$ NMR $(400 \mathrm{~Hz}, \mathrm{DMSO}-d 6)$ and ${ }^{13} \mathrm{C}$ NMR (100 Hz, DMSO-d6) spectra of $\mathrm{H}_{3} \mathrm{CbdcpCl}$ Ligand, Figure S6: The IR spectra of ligand $\mathrm{H} 3 \mathrm{CbdcpCl}$, complex 1, 2 and 3, Table S1: Bond lengths [A] and angles [ ${ }^{\circ}$ ] for 1-3, Table S2: Hydrogen bonds for 1 [ $\AA^{\circ}$ and ${ }^{\circ}$ ].

Acknowledgments: This work was supported by the National Natural Science Foundation of China (Projects 21371151, 21461029 and 21561033) and the Yunnan Province doctoral newcomer Award (YN2015015 and YN2014017).

Author Contributions: Yulu Ma and Qihua Zhao designed the experiments and wrote the paper, Yulu Ma and Lin Du carried out the synthesis experiments, Kaimin Wang performed X-ray structure determination and Yulu Ma analyzed the results, Kaimin Wang performed X-ray powder diffraction analysis, Lin Du performed the other experiments. All authors took part in the discussion processes and have approved the final manuscript.

Conflicts of Interest: The authors declare no conflict of interest. 


\section{Appendix}

CCDC 1522571 (1), 1522572 (2) and 1522573 (3) contain the supplementary crystallographic data for this paper. These data can be obtained free of charge from the Cambridge Crystallographic Data Center via the internet at http://www.ccdc.cam.ac.uk/data_request/cif, or by e-mailing data_request@ccdc.cam.ac.uk.

\section{References}

1. Yu, J.; Cui, Y.; Wu, C.-D.; Yang, Y.; Chen, B.; Qian, G. Two-Photon Responsive Metal-Organic Framework. J. Am. Chem. Soc. 2015, 137, 4026-4029. [CrossRef] [PubMed]

2. Wang, K.; Yi, X.-C.; Wang, X.; Li, X.-B.; Gao, E.-Q. Structures and magnetic properties of copper(II) and manganese(II) polymers derived from pseudohalides and a flexible zwitterionic dicarboxylate ligand. Dalton Trans. 2013, 42, 8748-8760. [CrossRef] [PubMed]

3. Liu, F.; Li, P.; Gao, W.; Zhang, X.-M.; Liu, J.-P. Synthesis, structure and magnetism of two metal(II) compounds based on two new zwitterionic ligands. Inorg. Chim. Acta 2016, 451, 116-122. [CrossRef]

4. Wang, Y.-Q.; Cheng, A.-L.; Liu, P.-P.; Gao, E.-Q. Unusual composition dependence of magnetic relaxation for $\mathrm{Co}^{\mathrm{II}}{ }_{1-x} \mathrm{Ni}^{\mathrm{II}}{ }_{x}$ chain-based metal-organic frameworks. Chem. Commun. 2013, 49, 6995-6997. [CrossRef] [PubMed]

5. Ning, Y.; Wang, L.; Yang, G.-P.; Wu, Y.; Bai, N.; Zhang, W.; Wang, Y.-Y. Four new lanthanide-organic frameworks: Selective luminescent sensing and magnetic properties. Dalton Trans. 2016, 45, 12800-12806. [CrossRef] [PubMed]

6. Hu, T.-P.; Xue, Z.-J.; Zheng, B.-H.; Wang, X.-Q.; Hao, X.-N.; Song, Y. Two novel nickel(II) and cobalt(II) metal-organic frameworks based on a rigid aromatic multicarboxylate ligand: syntheses, structural characterization and magnetic properties. CrystEngComm 2016, 18, 5386-5392. [CrossRef]

7. Xu, J.; Zhuo, Q.; Fu, R.; Cheng, H.; Tang, X.; Ma, Y.; Xie, J.; Yuan, R. A 2D metal-organic framework for selective adsorptions on organic dyes. Inorg. Chim. Acta 2016, 446, 198-202. [CrossRef]

8. Yang, J.; Ma, J.-F.; Liu, Y.-Y.; Ma, J.-C.; Batten, S.R. Organic-Acid Effect on the Structures of a Series of Lead(II) Complexes. Inorg. Chem. 2007, 46, 6542-6555. [CrossRef] [PubMed]

9. Pan, M.; Du, B.-B.; Zhu, Y.-X.; Yue, M.-Q.; Wei, Z.-W.; Su, C.-Y. Highly Efficient Visible-to-NIR Luminescence of Lanthanide(III) Complexes with Zwitterionic Ligands Bearing Charge-Transfer Character: Beyond Triplet Sensitization. Chem. Eur. J. 2016, 22, 2440-2451. [CrossRef] [PubMed]

10. Meng, W.L.; Fan, J.; Okamura, T.; Kawaguchi, H.; Lv, Y.; Sun, W.Y.; Ueyama, N. Construction of Mononuclear Copper(II) and Trinuclear Cobalt(II) Complexes Based on Asymmetric Salamo-Type Ligands. Z. Anorg. Allg. Chem. 2006, 632, 189-196.

11. Ma, Y.; Zhang, J.-Y.; Cheng, A.-L.; Sun, Q.; Gao, E.-Q.; Liu, C.-M. Antiferro- and Ferromagnetic Interactions in $\mathrm{Mn}(\mathrm{II}), \mathrm{Co}(\mathrm{II})$, and Ni(II) Compounds with Mixed Azide-Carboxylate Bridges. Inorg. Chem. 2009, 48, 6142-6151. [CrossRef] [PubMed]

12. Nakanishi, T.; Sato, O. Synthesis, Structure, and Magnetic Properties of New Spin Crossover Fe(II) Complexes Forming Short Hydrogen Bonds with Substituted Dicarboxylic Acids. Crystals 2016, 6, 131. [CrossRef]

13. Suckert, S.; Germann, L.S.; Dinnebier, R.E.; Werner, J.; Näther, C. Synthesis, Structures and Properties of Cobalt Thiocyanate Coordination Compounds with 4-(hydroxymethyl)pyridine as Co-ligand. Crystals 2016, 6, 38. [CrossRef]

14. Yang, Q.-Y.; Pan, M.; Wei, S.-C.; Hsu, C.-W.; Lehn, J.-M.; Su, C.-Y. Photoluminescent 3D lanthanide MOFs with a rare (10,3)-d net based on a new tripodal organic linker. CrystEngComm 2014, 16, 6469-6475. [CrossRef]

15. Sun, J.-K.; Cai, L.-X.; Chen, Y.-J.; Li, Z.-H.; Zhang, J. Reversible luminescence switch in a photochromic metal-organic framework. Chem. Commun. 2011, 47, 6870-6872. [CrossRef] [PubMed]

16. Semitut, E.; Komarov, V.; Sukhikh, T.; Filatov, E.; Potapov, A. Synthesis, Crystal Structure and Thermal Stability of 1D Linear Silver(I) Coordination Polymers with 1,1,2,2-Tetra(pyrazol-1-yl)ethane. Crystals 2016, 6, 138. [CrossRef] 
17. Yang, S.-P.; Chen, S.-R.; Liu, S.-W.; Tang, X.-Y.; Qin, L.; Qiu, G.-H.; Chen, J.-X.; Chen, W.-H. Platforms Formed from a Three-Dimensional Cu-Based Zwitterionic Metal-Organic Framework and Probe ss-DNA: Selective Fluorescent Biosensors for Human Immunodeficiency Virus 1 ds-DNA and Sudan Virus RNA Sequences. Anal. Chem. 2015, 87, 12206-12214. [CrossRef] [PubMed]

18. Qin, L.; Lin, L.-X.; Fang, Z.-P.; Yang, S.-P.; Qiu, G.-H.; Chen, J.-X.; Chen, W.-H. A water-stable metal-organic framework of a zwitterionic carboxylate with dysprosium: A sensing platform for Ebolavirus RNA sequences. Chem. Commun. 2016, 52, 132-135. [CrossRef] [PubMed]

19. Chen, J.-X.; Zhao, H.-Q.; Li, H.-H.; Huang, S.-L.; Ding, N.-N.; Chen, W.-H.; Young, D.J.; Zhang, W.-H.; Hor, T.S.A. Bent tritopic carboxylates for coordination networks: Clues to the origin of self-penetration. CrystEngComm 2014, 16, 7722-7730. [CrossRef]

20. Higuchi, M.; Tanaka, D.; Horike, S.; Sakamoto, H.; Nakamura, K.; Takashima, Y.; Hijikata, Y.; Yanai, N.; Kim, J.; Kato, K.; et al. Porous Coordination Polymer with Pyridinium Cationic Surface, $\left[\mathrm{Zn}_{2}(\mathrm{tpa})_{2}(\mathrm{cpb})\right]$. J. Am. Chem. Soc. 2009, 131, 10336-10337. [CrossRef] [PubMed]

21. Sun, J.-K.; Ji, M.; Chen, C.; Wang, W.-G.; Wang, P.; Chen, R.-P.; Zhang, J. A charge-polarized porous metal-organic framework for gas chromatographic separation of alcohols from water. Chem. Commun. 2013, 49, 1624-1626. [CrossRef] [PubMed]

22. Li, H.-N.; Li, H.-Y.; Li, L.-K.; Xu, L.; Hou, K.; Zang, S.-Q.; Mak, T.C.W. Syntheses, Structures, and Photoluminescent Properties of Lanthanide Coordination Polymers Based on a Zwitterionic Aromatic Polycarboxylate Ligand. Cryst. Growth Des. 2015, 15, 4331-4340. [CrossRef]

23. Chen, J.-X.; Chen, M.; Ding, N.-N.; Chen, W.-H.; Zhang, W.-H.; Hor, T.S.A.; Young, D.J. Transmetalation of a Dodecahedral Nag Aggregate-Based Polymer: A Facile Route to Water Stable Cu(II) Coordination Networks. Inorg. Chem. 2014, 53, 7446-7454. [CrossRef] [PubMed]

24. Lee, Y.H.; Kubota, E.; Fuyuhiro, A.; Kawata, S.; Harrowfield, J.M. Yang Kim and Shinya Hayami, Synthesis, structure and luminescence properties of $\mathrm{Cu}(\mathrm{II}), \mathrm{Zn}(\mathrm{II})$ and $\mathrm{Cd}(\mathrm{II})$ complexes with $4^{\prime}$-terphenylterpyridine. Dalton Trans. 2012, 41, 10825-10831. [CrossRef] [PubMed]

25. Zhang, A.-J.; Chen, C.-J.; Lou, D.-Y.; Miao, Y.-H.; Qiao, C.-X.; Hu, J.-B. Nickel(II), Cadmium(II), and Copper(II) Complexes Based on Ditopic Terpyridine Derivative Ligand: Syntheses, Crystal Structures, and Luminescent Properties. Z. Anorg. Allg. Chem. 2016, 642, 817-822. [CrossRef]

26. Li, H.-Y.; Cao, L.-H.; Wei, Y.-L.; Xu, H.; Zang, S.-Q. Construction of a series of metal-organic frameworks based on novel flexible ligand 4-carboxy-1-(3,5-dicarboxy-benzyl)-pyridinium chloride and selective d-block metal ions: crystal structures and photoluminescence. CrystEngComm 2015, 17, 6297-6307. [CrossRef]

27. Wang, K.-M.; Du, L.; Ma, Y.-L.; Zhao, J.-S.; Wang, Q.; Yan, T.; Zhao, Q.-H. Multifunctional chemical sensors and luminescent thermometers based on lanthanide metal-organic framework materials. CrystEngComm 2016, 18, 2690-2700. [CrossRef]

(C) 2017 by the authors; licensee MDPI, Basel, Switzerland. This article is an open access article distributed under the terms and conditions of the Creative Commons Attribution (CC BY) license (http://creativecommons.org/licenses/by/4.0/). 